that propranolol in a single dose of $120 \mathrm{mg}$ caused normal people to feel significantly more troubled than when on placebo and that these feelings occurred in the absence of sedation. Perhaps alteration of bodily sensations may be perceived as unpleasant by those who do not complain of somatic anxiety. The therapeutic indications for propranolol in pathological anxiety seem to be confined to patients who do not complain of anxiety even though their somatic symptoms are clearly due to anxiety. Symptoms caused by tachycardia and tremor, both of which are significantly lessened by betaadrenoceptor blockade in anxious patients (Turner et al., 1965; Marsden et al., 1968; Tyrer and Lader, 1973), are especially likely to be helped. In such patients the removal of the symptom is enough to bring considerable clinical relief. This supports the view that bodily symptoms may be more fundamental in morbid emotion than is usually thought (Tyrer, 1973), and is consistent with the long-standing clinical impression that patients with somatic complaints are best treated by somatic therapy (Misch, 1935).

The results of our study are also consistent with previous reports of the effectiveness of beta-receptor blockade in other conditions. It could be argued that the primary complaint in "hypendynamic beta-adrenergic circulatory state" (Frohlich et al., 1966), "nervous heant complaint" (Nordenfelt et al., 1968), "hyperventilation syndrome" (Suzman, 1968), and "vasoregulatory asthenia" (Holmgren et al., 1957) is that of anxiety presenting in the guise of somatic malfunotion. In all these conditions beta-receptor blockade is beneficial (Marsden, 1971). If the speotrum of somatic anxiety is extended to include such functional disorders the type of patient suitable for treatment with beta-blocking agents is better defined. It remains to be seen whether there are differences in response between individual beta-blocking agents but from our knowledge of their clinical effects in other conditions this seems unlikely, provided they are given in equipotent dosage (Thadani et al., 1973). The clinical presentation of anxiety is so varied and the pharmacological differences between the beta-blocking drugs so small by comparison that it is the selection of the right patient for treatment rather than choice of drug which is likely to be critical for success.

We are grateful to Dr. P. Bayliss of I.C.I. Pharmaceuticals Division for supplying the capsules of propranolol, diazepam, and placebo, and to Vivien Maclean for co-ordinating their allocation. This work was supported by the Medical Research Council.

Requests for reprints should be sent to Dr. Tyrer.

\section{References}

Bonn, J. A., Turner, P., and Hicks, D. C. (1972). Lancet, 1, 814. Conway, M. (1971). Practitioner, 206, 795.

Frohlich, E. D., Dunstan, H. P., and Page, I. H. (1966). Archives of Internal Medicine, $117,614$.

Granville-Grossman, K. L., and Turner, P. (1966). Lancet, 1, 788.

Hamilton, M. (1959). British fournal of Medical Psychology, 32, 50

Holmgren, A., et al. (1957). Acta Medica Scandinavica, 158, 437.

Lader, M. H., and Marks, I. M. (1971). Clinical Anxiety, p. 99. London, Heinemann Lader, M. H., and Tyrer, P. J. (1972). British fournal of Pharmacology, 45,

McMillin, W. P. (1973). Lancet, 1, 1193.

Marsden, C. D., Gimlette, T. M. D., McAllister, R. G., Owen, D. A. L., and Miller, T. N. (1968). Acta Endocrinologica (Kobenhavn), 57, 353.

Marsden, C. W. (1971). Postgraduate Medical fournal, Suppl. 47, 100.

Misch, W. (1935). Fournal of Mental Science, 81, 389.

Nordenfelt, I., Persson, S., and Redfors, A. (1968). Acta Medica Scandinavica, 184, 465.

Ramsay, I., Greer, S., and Bagley, C. (1973). British fournal of Psychiatry, $122,555$.

Roberts, J. M., and Hamilton, M. (1958). Fournal of Mental Science, 104, 1052 .

Shand, D. G., Nuckolls, E. M., and Oates, J. A. (1970). Clinical Pharmacology and Therapeutics, 11, 112.

Siegel, S. (1956). Non-parametric Statistics for the Behavioral Sciences, p. 229. New York, McGraw-Hill.

Suzman, M. M. (1968). Annals of Internal Medicine, 68, 1194.

Thadani, U., et al. (1973). British Medical fournal, $1,138$.

Turner, P., Granville-Grossman, K. L., and Smart, J. V. (1965). Lancet, 2, 1316.

Tyrer, P. J. (1973). Lancet, 1, 915.

Tyrer, P. J., and Lader, M. H. (1973). Clinical Pharmacology and Therapeutics, 14, 418 .

Van der Kleijn, E. (1971). Annals of the New York Academy of Sciences, 179,

Wheatley, D. (1969). British Fournal of Psychiatry, 115, 1411.

Winer, B. J. (1962). Statistical Principles in Experimental Design. New York, McGraw-Hill.

\title{
Long-term Chelation Therapy in Thalassaemia Major: Effect on Liver Iron Concentration, Liver Histology, and Clinical Progress
}

\author{
MICHAEL BARRY, DAVID M. FLYNN, ELIZABETH A. LETSKY, R. A. RISDON
}

British Medical fournal, 1974, 2, 16-20

\section{Summary}

A prospective trial of continuous chelation therapy in children with homozygous thalassaemia on a high transfusion

Department of Medicine, Royal Free Hospital, London WC1X 8LF MICHAEL BARRY, M.D., M.R.C.P., Senior Medical Registrar

Hospital for Sick Children, Great Ormond Street, London W.C.1

DAVID M. FLYNN, M.D., M.R.C.P., Honorary Consultant Physician (Present appointment: Consultant Paediatrician, Royal Free Hospital, London.)

Department of Haematology, Institute of Child Health, London W.C.1 ELIZABETH A. LETSKY, M.B., M.R.C.PATH., Lecturer in Haematology

Department of Morbid Anatomy, Institute of Child Health, London W.C.1

R. A. RISDON, M.D., M.R.C.PATH., Senior Lecturer in Morbid Anatomy regimen was started in April 1966. The effect of treatment on iron concentration in the liver and on hepatic histology was examined in 49 biopsy specimens obtained from nine chelator-treated patients and nine control patients between April 1966 and April 1973.

Chelation therapy was associated with a significant reduction in liver iron concentration, and by the end of the trial the values for the two groups showed no overlap. A similar difference was seen in the amount of hepatic fibrosis, which showed little or no change in the chelator-treated patients but was progressive in the controls.

No major clinical differences were seen, probably because both groups included several older children who were heavily loaded with iron at the start of the trial. Among the younger patients, however, puberty was delayed in four of five controls but in only one of four chelator-treated children. Prepubertal growth rate was significantly greater in the chelatortreated patients than in the controls. 


\section{Introduction}

Iron overload has been recognized as a prominent feature of thalassaemia since Whipple and Bradfond (1936) emphasized the characteristic pattern of heavy visceral iron deposition, which they likened to that of adult haemochromatosis. At that time most patients with thalassaemia died in childhood from anaemia and cardiac failure, and the tissue damage typical of haemochromatosis was not seen. As the use of blood transfusions increased, however, survival was prolonged into adolescence and early adult life and haemochromatosis came to be reganded as a major cause of death (Frumin, et al., 1952; Howell and Wyatt, 1953; Ellis, et al., 1954). The relative importance of iron excess and tissue hypoxia in the genesis of ill-health and organ damage remained controversial, but the long-term outcome in children maintained on a high transfusion regimen suggests that iron overload is the major factor limiting life (Wolman, 1964; Wolman and Ontolani, 1969).

The need to minimize or prevent iron accumulation in thalassaemia is now generally acknowledged and much interest has attached to the use of iron-chelating agents in treatment. Two chelating agents, desferrioxamine and diethylenetrimine penta-acetate, have held the field for the past decade (Smith, 1962; Smith, 1964). Though urinary iron losses of $10-50 \mathrm{mg} /$ day can be achieved with either compound direct information about the effect of long-term chelation therapy on total iron-load is lacking and it is not known whether such treatment is beneficial. A long-term trial of continuous chelation therapy in thalassaemic children on a high transfusion regimen was started at the Hospital for Sick Children in 1966. This paper reports the changes in liver iron concentration and histology and the clinical progress in the chelatortreated and prospectively-selected control patients between 1966 and 1973.

\section{Patients and Methods}

The trial was started in April 1966, when 10 patients with $\beta$-thalassaemia major began continuous chelation therapy and were allocated to the treatment group. Ten patients who were to receive no chelators were selected as controls. Selection was performed so as to obtain two groups matched as closely as possible for sex, age, transfused iron load, and splenectomy status. One patient in each group failed to complete the trial. The details of the remaining 18 are summarized in the table. The mean age of the controls was slightly greater than that of the chelator-treated patients and the average amount of blood received per patient was also higher in the control group. These differences, which reflected the inclusion of three younger, less heavily transfused patients in the treated group, remained unchanged throughout the study and were not statistically significant.

Each patient attended the haemoglobinopathy clinic of the Hospital for Sick Children at intervals of 2-4 weeks and was transfused every 4-8 weeks so as to keep the haemoglobin concentration between 8.0 and $15.0 \mathrm{~g} / 100 \mathrm{ml}$. The amount of blood given at each transfusion was recorded. The chelatortreated patients received desferrioxamine mesylate $0.5 \mathrm{~g}$ in 2 $\mathrm{ml}$ water by intramuscular injection on 6 days each week, given at home by the district nurse, and diethylenetriamine penta-acetate $2 \mathrm{~g}$ intravenously with each unit of blood. The use of the latter drug eventually had to be stopped in four children owing to adverse reactions, desferrioxamine being given instead. The mean duration of chelation therapy in those patients receiving this treatment was 5.8 years (range $5 \cdot 2-6 \cdot 3$ years)

The first liver biopsies were performed in 15 of the 18 patients at the stant of the trial in 1966. Biopsy was first performed in one patient in 1967 and in one in 1969. Interim biopsies were performed in many patients in 1967 and 1969.
Final liver biopsies were performed in 17 patients between June 1971 and August 1972, and a specimen of liver obtained from the remaining patient at necropsy in April 1973. Biopsy was not performed in one patient in the control group until the end of the trial. Liver tissue for biopsy was obtained by percutaneous needle puncture under general anaesthesia except for wedge specimens taken from two patients at the time of splenectomy in 1972. The aims and conduct of the trial were approved by the ethics committe of the hospital and the informed consent of the parents was obtained both to inclusion in the trial and to every liver biopsy.

Assessment of Iron Stores. - Liver concentration was determined by the method of Barry and Sherlock (1971). Fresh specimens were oven-dried and weighed to the nearest 0.01 mg. Dulpicate biopsy specimens were taken in 10 cases; the standard error for a single specimen corresponded to a coefficient of variation of $6.6 \%$. Paraffin-embedded specimens were separated from the blocks by soaking in xylene and then dried. Five specimens were analysed in duplicate in the fresh state and after paraffin embedding respectively; the standard error of the difference between the means corresponded to a coefficient of variation of $7.0 \%$

Histological Assessment.-The liver biopsy specimens were examined histologically without knowledge of their origins, the clinical details, or the results of chemical analyses. The extent of hepatic fibrosis was determined on camera lucida drawings made from sections of each biopsy, the area of a section occupied by fibrous tissue being expressed as a percentage of the total area of the section. This has been termed the "ffibrosis index" (Risdon et al., 1974).

\section{Results}

The difference in mean liver iron concentration between the groups at the start of the trial was not significant (table). Though preliminary biopsies were not performed in all the patients this probably did not significantly affect the initial comparison. By the end of the trial the two groups showed no overlap in liver iron concentration and the difference between the respective means was highly significant. This was due to a pronounced rise $(t=2.15, \mathrm{P}<0.05)$ in the value for the controls, that for the chelator-treated group showing relatively little change.

\begin{tabular}{|c|c|c|c|c|c|}
\hline & $\begin{array}{c}\text { Group } \\
\text { (No. of Patients) }\end{array}$ & $\begin{array}{c}\text { Age } \\
\text { (Months) }\end{array}$ & $\begin{array}{l}\text { Units } \\
\text { Trans- } \\
\text { fused }\end{array}$ & $\begin{array}{c}\text { Liver Iron } \\
\text { Concentration } \\
\text { (\% dry weight) }\end{array}$ & $\begin{array}{l}\text { No. of } \\
\text { Splenec- } \\
\text { tomized } \\
\text { Patients }\end{array}$ \\
\hline \multirow{2}{*}{1966} & $\begin{array}{l}\text { Chelator-treated (9) } \\
\text { Controls (9) }\end{array}$ & $\begin{array}{l}74 \pm 9 \\
91 \pm 11\end{array}$ & $\begin{array}{l}58 \pm 19 \\
73 \pm 11\end{array}$ & $\begin{array}{l}2 \cdot 20 \pm 0.43^{*} \\
3 \cdot 13 \pm 0.48 \dagger\end{array}$ & $\begin{array}{l}5 \\
4\end{array}$ \\
\hline & $\begin{array}{c}\text { Significance of } \\
\text { difference } \neq\end{array}$ & $P>0.2$ & $P>0.4$ & $P>0.1$ & \\
\hline \multirow{2}{*}{$1971-2$} & $\begin{array}{l}\text { Chelator-treated (9) } \\
\text { Controls (9) }\end{array}$ & $\begin{array}{l}142 \pm 10 \\
164 \pm 11\end{array}$ & $\begin{array}{l}194 \pm 33 \\
223 \pm 19\end{array}$ & $\begin{array}{l}2 \cdot 59 \pm 0 \cdot 17 \\
4 \cdot 22 \pm 0 \cdot 24\end{array}$ & $\begin{array}{l}5 \\
4\end{array}$ \\
\hline & $\begin{array}{c}\text { Significance of } \\
\text { difference } \neq\end{array}$ & $P>0.1$ & $P>0.4$ & $P<0.001$ & \\
\hline
\end{tabular}

* Mean of eight available biopsy specimens.

tMean of seven available biopsy specimens.

$\ddagger t$ test.

Relation between Liver Iron Concentration and Transfused Load.-In both the chelator-treated and the control patients liver inon concentration increased with the amount of blood transfused but the rise was greater in the controls (fig. 1). In each group the relationship was best expressed as an exponential function of the transfused load and analysis of covariance confirmed that the respective regression lines were significantly non-coincident $(t=4.27, P<0.001)$ and 


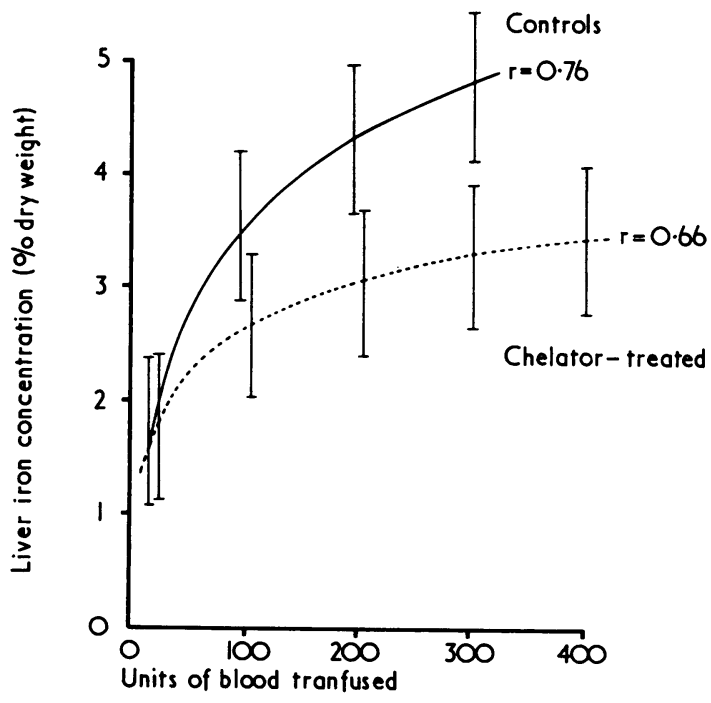

FIG. 1-Regression lines ( \pm S.E. of estimate) for liver iron concentration on transfused load in chelator-treated and control groups. Regression equation for chelator-treated patients was $y=1.276 \log x+0 \cdot 109$, and for controls $y=2.572 \log x-1.603$. Both correlation coefficients were significant $(\mathbf{P}<0.001)$

different in slope $(t=2.08, P<0.05)$. Higher liver iron levels relative to transfused load might have been expected in patients who had undergone spleneotomy but no such tendency was observed in either group.

Chelator-treated Patients.-The findings in serial biopsy specimens from the individual patients are shown in fig. 2 . The patients fell into two groups. The first group comprised four children with liver iron levels greater than $3 \%$ dry weight at the stant of the trial; two subsequently showed a pronounced fall in liver iron concentration and two maintained an approximately constant level. The second group comprised five children with initial values of less than $2.4 \%$ dry weight. In these liver iron concentration showed a highly significant exponential rise with increasing transfused load $(r$ $=0.88, \mathrm{P}<0.001$ ) to reach a level of $3 \%$ dry weight after about 240 units of blood had been given.

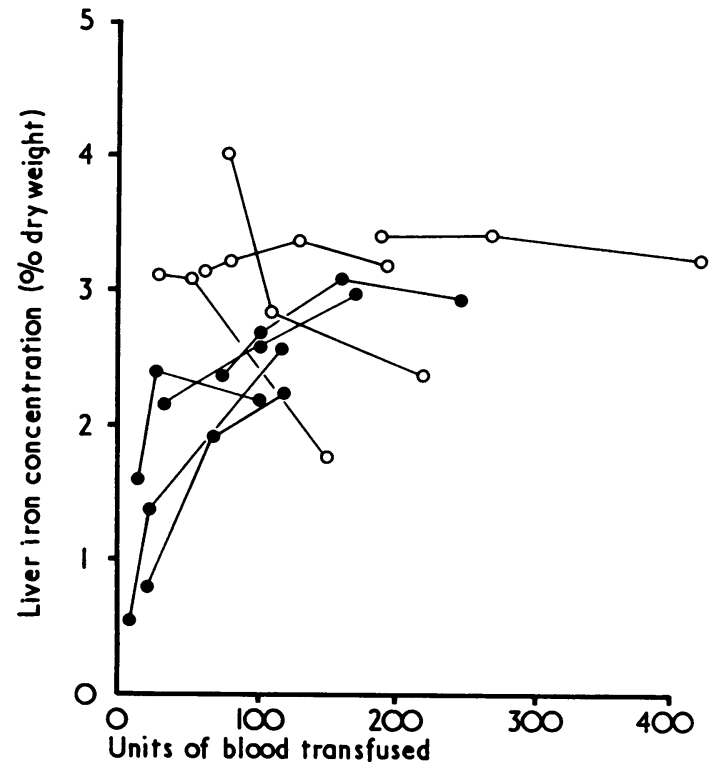

FIG. 2-Liver iron concentration in serial biopsy specimens FIG. 2 - Liver iron concentration in serial biopsy specimens from patients receiving chelation therapy. initial liver iron levels more than $3 \%$ dry weight.
Patients with initial values less than $2 \cdot 4 \%$ dry weight.
Control Patients.-Liver iron concentration increased in seven patients in whom serial biopsies were performed, and fell in one (fig. 3). In one patient a liver biopsy was not performed until the end of the trial. The rate of increase in liver iron concentration relative to the transfused load diminished as the values approached $4 \%$ dry weight after about 100 units of blood had been given.

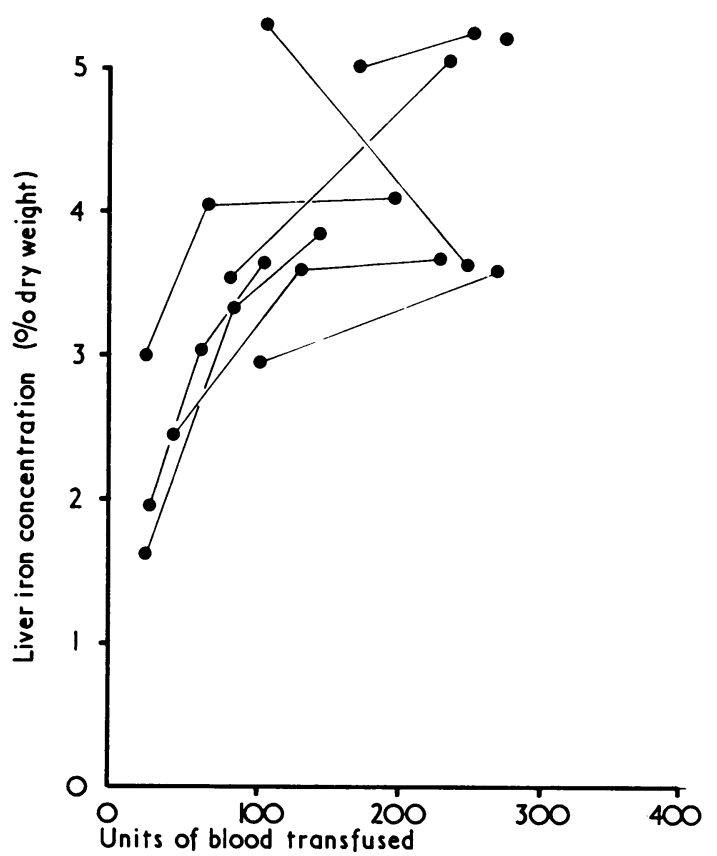

FIG. 3-Liver iron concentration in serial biopsy specimens from control patients.

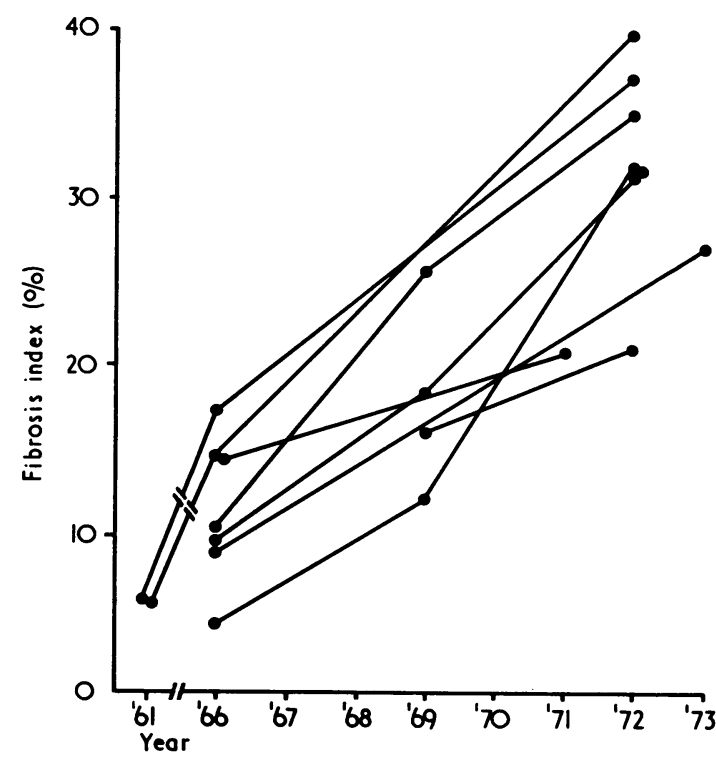

FIG 4-Progression of hepatic fibrosis in individual control patients. Also shown are findings in two patients in whom biopsy had previously been carried out in 1961 .

Histopathological Findings.-At the stant of the trial the fibrosis indices for the two groups overlapped widely. The mean value for the controls was slightly higher than that for the chelator-treated patients, the difference just attaining statistical significance $(t=2.31,0.025<P<0.05)$. By the end of the trial, however, there was no overlap in the values for the two groups and the difference was highly significant $(t=$ 


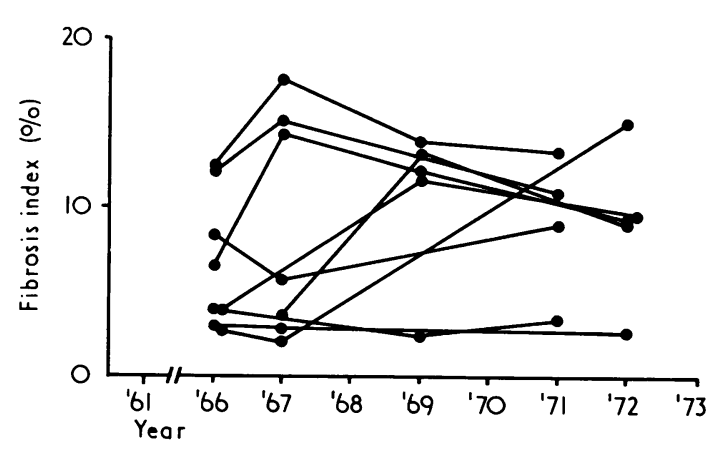

FIG. 5-Progression of hepatic fibrosis in individual chelatortreated patients.

$8.28, \mathrm{P}<0.001)$. This was owing to the occurrence of progressive fibrosis in the control patients (fig. 4), the amount of fibrosis in the chelator-treated group showing no significant overall change (fig. 5). At the end of the trial severe fibrosis or cirrhosis (corresponding to fibrosis indices of more than $25 \%$ ) were present in six of the controls but in none of the chelator-treated patients.

Clinical Findings.-There were no major clinical differences between the two groups. One patient in the control group subsequently died but none died in the chelator-treated group. There were small differences favouring the chelator-treated patients in height-velocity in prepubental children $(P<0.05)$ and in height at the end of the study (not significant). There was a similar incidence of diabetes mellitus (three and two cases) and of pericarditis with cardiac failure (three and four cases) in the chelator-treated and control groups respectively. One control patient had hypoparathyroidism in addition to diabetes mellitus. There was a delay of more than two standard deviations in achieving the pubenty ratings (Marshall and Tanner, 1970) in five out of nine patients in whom data were available. Pubenty was delayed in four out of five controls but in only one out of four chelator-treated children. A pubertal growth spurt occurred in the patients with a normal pubenty but not in those with pubertal delay.

\section{Discussion}

A difficulty inherent in comparative trials in thalassaemia is that the patients tend to vary widely in many aspects of the disease and matched observations are difficult to obtain. Our study was controlled in that the chelator-treated patients were compared prospectively with other thalassaemics who were matched as closely as possible for sex, age, and transfusional status, and were maintained on a similar high transfusion regimen. The transfusional requirements of the children is one factor panticularly difficult to control. Though the present children were transfused according to individual need little discrepancy developed between the two groups during the period of study. One advantage of the high transfusion regimen is that the major endogenous factor influencing iron absorption-namely, erythropoiesis - can be assumed to have been minimized so that iron accumulation can be largely, if not completely, attributed to the blood received. Thus the effeot of chelation therapy on iron stores in the two groups can be compared by using the amounts of blood transfused as a reference.

Apart from four children in the chelator-treated group with initially high values, liver iron concentration increased progressively in both groups during the course of the study. Nevertheless, the rate of increase relative to the transfused load was significantly lower in the chelator-treated children than in the controls. Though there was no significant difference in liver iron concentration between the groups at the be- ginning of the trial the respective values showed no overlap at the end. In the chelator-treated children liver iron concentration seemed to reach a maximum of about $3 \%$ dry weight after 250 units of blood had been given, suggesting that they were then in iron balance. In the controls, on the other hand, liver iron was continuing to rise, albeit at a reduced rate, above $4 \%$ dry weight at a similar transfused load. The decreasing rate of hepatic iron deposition relative to the amount of blood being given in children not receiving chelating agents may be due to the onset of spontaneous iron excretion as total body iron content becomes massive (Barry and Flynn, 1974). Berry and Marshall (1967) found that the stainable iron in hepatic parenchymal cells was increased in patients with thalassaemia who had undergone splenectomy as compared with patients who had not. Nevertheless, we found no tendency for total liver iron in children who had undergone splenectomy in either group to be higher, relative to the transfused load, than in children who had not.

The hepatic histological findings showed a clear-cut advantage in favour of the chelator-treated children. With the prolonged survival that regular transfusion now confers in thalassaemia severe fibrosis or cirrhosis is an almost constant finding at necropsy (Frumin et al., 1952; Howell and Wyatt, 1953; Ellis et al., 1955; Witzleben and Wyatt, 1955) and the progressive fibrosis observed in our control patients conforms with this. The lack of progressive fibrosis in the chelatortreated patients is of particular interest since most of these patients had liver iron concentrations in excess of $1.8 \%$ dry weight throughout much or all of the trial period. This is the lower limit of the range generally found in untreated idiopathic haemochromatosis when it is usually accompanied by severe fibrosis or cirrhosis (Barry, 1973). The limited though significant reduction in tissue iron accumulation achieved by chelation therapy would appear to have at least delayed the progression of liver injury.

Pubertal delay is almost invariable in heavily transfused patients with thalassaemia and the occurrence of a normal pubenty in severely affected patients is remarkable. Little difference was seen in the incidence of the endocrine and cardiac complications in the two groups. These are usually assumed to be due to massive iron deposition and are expected only in older patients. Neventheless, those of our patients who are now in their second decade were already heavily loaded with iron when chelation therapy was started and it is not surprising that chelation therapy seems to have had little clinical effect. In younger patients the reverse is true and it may well be that in these the endocrine and cardiac complications will be diminished or delayed. Though it is now too early to discern any definite clinical advantage from chelation therapy the greater growth rate in the chelated prepubental children is encouraging.

In conclusion, this study has shown that long-term iron chelation therapy significantly reduces hepatic iron accumulation in patients maintained on a high transfusion regimen and that this is accompanied by a significant retardation in the progression of hepatic fibrosis. Though the trial was primarily concerned with the management of children with thalassaemia the findings are also relevant to the management of other iron-loading anaemias. Longer-term studies are necessary to establish the clinical benefits accruing from this treatment but our preliminary findings are encouraging. The feasibility of using larger doses of desferrioxamine (for instance, one gramme daily) and the advantages to be gained thereby are further points that merit investigation.

We are grateful to the physicians of the Hospital for Sick Children for permission to study patients under their care and to Professors R. M. Hardisty and Sheila Sherlock for their continued interest and support. We are indebted to Dr. E. N. Thompson and Dr. Peter de Buse and many other members of the staff of the hospital who helped in the management of the patients, 
and to Dr. W. C. Marshall who performed all the earlier liver biopsies. Dr. J. G. Domenet of Geigy Pharmaceuticals and Dr. D. M. Burley of CIBA generously provided diethylenetriamine penta-acetate and desferrioxamine respectively.

\section{References}

Barry, M. (1973). Fournal of the Royal College of Physicians of London, 8, 52. Barry, M., and Flynn, D. M. (1974). In preparation.

Barry, M., and Sherlock, S. (1971). Lancet, 1, 100.

Berry, C. L., and Marshall, W. C. (1967). Lancet, 1, 1031.
Ellis, J. T., Schulman, I., and Smith, C. H. (1954). American fournal of Pathology, 30, 287

Frumin, A. M., Waldman, S., and Morris, P. (1952). Pediatrics, 9, 290.

Howell, J., and Wyatt, J. P. (1953). Archives of Pathology, 55, 423.

Marshall, W. A., and Tanner, J. M. (1970). Archives of Disease in Childhood,

45, 13.
Risdon, A. R., Barry, M., and Flynn, D. M. (1974). In preparation.

Smith, R. S. (1962). British Medical fournal, 2, 1577

Smith, R. S. (1964). Annals of the New York Academy of Sciences, 119, 776.

Whipple, G. H., and Bradford, W. L. (1936). Fournal of Pediatrics, 9, 279.

Witzleben, C. L., and Wyatt, J. P. (1961). Fournal of Pathology and Bacteriology, 82, 1 .

Wolman, I. J. (1964). Annals of the New York Academy of Sciences, 119, 736.

Wolman, I. J., and Ortolani, M. (1969). Annals of the New York Academy of Sciences, 165, 407.

\section{Fine-needle Aspiration Biopsy of Spleen in Diagnosis of Generalized Amyloidosis}

\section{A. PASTERNACK}

British Medical fournal, 1974, 2, 20-22

\section{Summary}

Fine-needle aspiration biopsy of the spleen was performed on 18 patients shown to have amyloid deposits in other organs and on 17 control patients being investigated for proteinuria. Of the 18 patients with amyloid disease smears of splenic aspirate were positive in all cases, renal biopsy was positive in 16 out of 16 cases, and rectal biopsy was positive in seven out of 11 cases. None of the splenic smears were positive in the 17 control patients and no amyloid was found in the kidney in 15 of these patients on whom renal biopsy was performed. Splenic aspirate biopsy seems to be a simple and safe procedure for the diagnosis of amyloidosis. It is as accurate as renal biopsy and more accurate than rectal biopsy.

Fourth Department of Medicine, University Central Hospital, 00170 Helsinki 17, Finland

A. PASTERNACK, M.D., Associate Professor

\section{Introduction}

Generalized amyloidosis is most often diagnosed by percutaneous biopsy of the kidney or biopsy of the rectal mucasa. There is a need, however, for safer but equally reliable procedures which are easy to perform on large groups of patients. This paper reponts the results of diagnosis by fine-needle aspiration biopsy of the spleen.

\section{Patients and Methods}

Fine-needle aspiration biopsy of the spleen was performed in 35 patients. Eighteen had been or were later shown to have amyloidosis by biopsy of the kidney, rectum, or other organ (table I). The remaining 17 patients ( 7 women, 10 men), who served as controls were in hospital for the investigation of proteinuria (table II). A kidney biopsy was performed within one year in all but five of the patients in the amyloidosis group. The spleen was aspirated by means of a disposable $0.8 \times 80 \mathrm{~mm}$ needle on a disposable $20-\mathrm{ml}$ syringe with Luer adaptor. The spleen was located by percussion and the needle was usually insented into the tenth intercostal space about $3-5 \mathrm{~cm}$ dorsally to the mid-axillary line. To avoid dam-

TABLE I-Clinical Data and Biopsy Findings in 18 Patients with Generalized Amyloidosis. Median Age 42.5 Years

\begin{tabular}{|c|c|c|c|c|c|c|c|c|c|}
\hline \multirow[t]{2}{*}{$\begin{array}{l}\text { Case } \\
\text { No. }\end{array}$} & \multirow[t]{2}{*}{ Sex } & \multirow[t]{2}{*}{$\begin{array}{c}\text { Age } \\
\text { (Years) }\end{array}$} & \multirow[t]{2}{*}{ Diagnosis } & \multicolumn{3}{|c|}{ Amyloid Present in: } & \multicolumn{2}{|c|}{$\begin{array}{l}\text { Amyloid in Aspirate } \\
\text { from Spleen }\end{array}$} & \multirow[t]{2}{*}{ Timing of Biopsies } \\
\hline & & & & Kidney & Rectum & Other Sites & Amount & Localization & \\
\hline 1 & F. & 65 & Rheumatoid arthritis & & + & Gingiva + , liver + & +++ & Diffuse & \\
\hline 2 & M. & 37 & Ankylosing spondylitis & + & + & $\begin{array}{l}\text { Gingiva - } \\
\text { jejunum }+\end{array}$ & & Diffuse & Within a three-year period \\
\hline $\begin{array}{l}3 \\
4 \\
5\end{array}$ & $\begin{array}{l}\text { M. } \\
\text { M. }\end{array}$ & $\begin{array}{l}35 \\
43 \\
50\end{array}$ & $\begin{array}{l}\text { "” } \\
\text { Hereditary amyloidosis } \\
\text { with corneal dystrophy }\end{array}$ & $\stackrel{+}{+}$ & + & $\begin{array}{l}\text { Skin - } \\
\text { Skin }+ \text {, liver }+, \\
\text { gastric mucosa }+\end{array}$ & $\begin{array}{l}++ \\
++ \\
++\end{array}$ & $\begin{array}{l}\text { Perivascular } \\
\text { Diffuse } \\
\text { Diffuse }\end{array}$ & 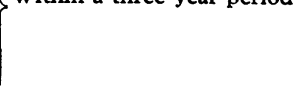 \\
\hline $\begin{array}{r}6 \\
7 \\
8 \\
9 \\
10 \\
11\end{array}$ & $\begin{array}{l}\text { M. } \\
\text { M. } \\
\text { M. } \\
\text { M. } \\
\text { F. }\end{array}$ & $\begin{array}{l}52 \\
34 \\
40 \\
28 \\
57 \\
52\end{array}$ & $\begin{array}{l}\text { Rheumatoid arthritis } \\
\text { ", } \\
\text { "” } \\
\text { Tuberculous osteitis } \\
\text { Hereditary amyloidosis } \\
\text { with corneal dystrophy }\end{array}$ & $\begin{array}{l}+ \\
+ \\
+ \\
+ \\
+ \\
+\end{array}$ & $\overline{-}$ & & $\begin{array}{l}+++ \\
+++ \\
++ \\
+++ \\
+\end{array}$ & $\begin{array}{l}\text { Diffuse } \\
\text { Diffuse } \\
\text { Perivascular } \\
\text { Diffuse } \\
\text { Diffuse? } \\
\text { Diffuse }\end{array}$ & Within a one-year period \\
\hline $\begin{array}{l}12 \\
13\end{array}$ & $\begin{array}{l}\text { M. } \\
\text { F. }\end{array}$ & $\begin{array}{l}46 \\
17\end{array}$ & $\begin{array}{l}\text { Rheumatoid arthritis } \\
\text { Juvenile rreumatoid } \\
\text { arthritis }\end{array}$ & + & $\stackrel{+}{+}$ & & + & $\begin{array}{l}\text { Perivascular ? } \\
\text { Diffuse }\end{array}$ & \\
\hline $\begin{array}{l}14 \\
15 \\
16 \\
17\end{array}$ & $\begin{array}{l}\text { M. } \\
\text { F. } \\
\text { F. } \\
\text { F. }\end{array}$ & $\begin{array}{l}36 \\
66 \\
54 \\
42\end{array}$ & $\begin{array}{l}\text { Ankylosing spondylitis } \\
\text { Bronchiectasiae } \\
\text { Skin tuberculosis }\end{array}$ & $\begin{array}{l}+ \\
+ \\
+ \\
-\end{array}$ & + & Jejunum - & $\begin{array}{l}++ \\
+++ \\
++ \\
+++\end{array}$ & $\begin{array}{l}\text { Diffuse } \\
\text { Diffuse } \\
\text { Diffuse } \\
\text { Diffuse }\end{array}$ & $\begin{array}{l}\text { During the same period in } \\
\text { hospital }\end{array}$ \\
\hline 18 & F. & 38 & Unknown & (2) +1 & - & & +++ & Perivascular & \\
\hline
\end{tabular}

